DOI: 10.2478/v10014-008-0009-2

Agrovoc descriptors: phaseolus vulgaris, gene pools, genetic variation, genotypes, genetic markers, polymorphism, provenance, geographical distribution

\title{
The efficiency of AFLP and SSR markers in genetic diversity estimation and gene pool classification of common bean (Phaseolus vulgaris $\mathbf{L}$.)
}

\author{
Marko MARAS ${ }^{1}$, Jelka ŠUŠTAR-VOZLIČ², Branka JAVORNIK ${ }^{3}$, Vladimir \\ MEGLIC̆ $^{4}$
}

Received Sept. 16, 2007; accepted April 28, 2008.

Delo je prispelo 16. sept. 2007; sprejeto 28. aprila 2008.

\begin{abstract}
The present work was conducted to evaluate AFLP (Amplified Fragment Length Polymorphism) and SSR (Simple Sequence Repeat) marker systems for their ability to detect genetic diversity within a set of 29 common bean accessions spanning both the Andean and Mesoamerican gene pools and to compare the efficiency of these two marker types in the classification of accessions according to the gene pools of origin. The ten AFLP primer combinations produced 112 polymorphic bands, while 14 SSR primer pairs generated 100 polymorphic bands. Almost two-fold higher value of expected heterozygosity was calculated for SSR (0.63) than for AFLP (0.32). As the result of a higher multiplex ratio component (11.20), higher marker index value was observed for AFLP (3.56) in comparison to SSR (0.63). The higher level of polymorphism detected by SSR markers has contributed to the lower genetic similarity estimates based on SSR markers (mean 0.25) as compared to AFLP markers (mean 0.88). The dendrograms generated with hierarchical UPGMA (Unweighted Pair Group Method with Arithmetic mean) cluster analysis of the Jaccard's similarity coefficient matrices revealed two major clusters, which were identified

Prispevek je del doktorskega dela 'Karakterizacija slovenskih genskih virov navadnega fižola (Phaseolus vulgaris L.) z morfološkimi, biokemijskimi in molekulskimi markerji', ki ga je pod mentorstvom prof. dr. Branke Javornik in doc. dr. Vladimirja Megliča napisal Marko Maras.

The manuscript is a part of the doctoral dissertation 'Morphological, biochemical and molecular characterization of Slovene common bean (Phaseolus vulgaris L.) genetic resources' written by Marko Maras (supervisors: prof. dr. Branka Javornik and dr. Vladimir Meglič).

1 Research Assistant, B. Sc., Agricultural Institute of Slovenia, SI-1000 Ljubljana, Hacquetova 17; e-mail: marko.maras@kis.si; phone: +386 12805 278; fax: +386 12805255

2 Research Assistant, Ph. D., Agricultural Institute of Slovenia, SI-1000 Ljubljana, Hacquetova 17

3 Prof., Ph. D., Biotechnical Faculty, University of Ljubljana, SI-1000 Ljubljana, Jamnikarjeva 101

4 Head of Crop and Seed Science Department, Ph. D., Agricultural Institute of Slovenia, SI1000 Ljubljana, Hacquetova 17
\end{abstract}


as the Andean and the Mesoamerican gene pools. Both marker systems showed comparable accuracy in grouping genotypes of common bean according to their gene pool of origin.

Key words: AFLP, SSR, gene pool, genetic diversity, Phaseolus vulgaris

\section{IZVLEČEK}

\section{ANALIZA UČINKOVITOSTI AFLP IN SSR MARKERSKIH SISTEMOV V PROUČEVANJU GENETSKE RAZNOLIKOSTI IN POREKLA NAVADNEGA FIŽOLA (Phaseolus vulgaris L.)}

V raziskavi smo na vzorcu 29 genotipov navadnega fižola različnega geografskega porekla (srednjeameriško, andsko) proučevali učinkovitost AFLP (polimorfizem dolžine pomnoženih restrikcijskih fragmentov) in SSR (enostavne ponavljajoče se sekvence) markerjev $v$ vrednotenju genetske raznolikosti in klasifikaciji navadnega fižola glede na poreklo. Z 10 pari AFLP začetnih oligonukleotidov smo $v$ verižni reakciji s polimerazo (PCR) pri 29 genotipih namnožili 112 polimorfnih fragmentov, s 14 pari SSR začetnih oligonukleotidov pa 100 . Za SSR markerski sistem $(0,63)$ smo v primerjavi z AFLP sistemom $(0,32)$ izračunali skoraj dvakrat višjo vrednost pričakovane heterozigotnosti polimorfnih lokusov. Pri AFLP sistemu smo zabeležili skoraj šestkrat višjo vrednost markerskega indeksa kot pri SSR $(3,56: 0,63)$, kar je posledica večjega povprečnega števila polimorfnih DNA fragmentov, namnoženih v posamezni AFLP analizi, in multipleksnega razmerja. Na podlagi odkritih polimorfizmov smo $v$ primerjavi $z$ AFLP S SSR sistemom izračunali nižjo povprečno vrednost genetske podobnosti med pari genotipov $(0,88: 0,25)$. Pri razvrščanju genotipov $v$ skupine $z$ metodo netehtane aritmetične sredine (UPGMA) na osnovi podobnosti so se akcesije ne glede na tip markerjev razvrstile $\vee 2$ skupini, ki ustrezata dvema izvornima geografskima regijama navadnega fižola (srednjeameriško, andsko). Rezultati raziskave kažejo, da sta SSR in AFLP markerska sistema podobno uspešna pri vrednotenju genetske raznolikosti navadnega fižola in njegovi klasifikaciji glede na poreklo.

Ključne besede: AFLP, SSR, genski sklad, genetska raznolikost, Phaseolus vulgaris

\section{INTRODUCTION}

Common bean (Phaseolus vulgaris L.) is a widely distributed crop of considerable importance in many countries around the world, representing a major protein input in the population diet. Two distinct gene pools of cultivated beans, as the result of different domestication events that occurred in the Andes (Peru and Argentina) and in Middle America (Mexico, Central America and Colombia) have been described (Gepts et al., 1986).

Biological evidence supporting this theory came originally from studies of variability in phaseolin, the major seed storage protein (Gepts, 1986). Seed size is the primary morphological characteristic used to discriminate between the gene pools; however, differences have also been observed for leaf and bracteole size and shape, flower color, internode length, pod beak position (Singh et al., 1991a), and climatic adaptation (Debouck et al., 1993). Studies of isozyme variation also revealed the existence of two gene pools within P. vulgaris (Singh et al., 1991b). Further evidences for the diversity between the Andean and Mesoamerican gene pools have been found by various molecular techniques. These include RFLP (Restriction Fragment Length Polymorphism) (Velasquez and Gepts, 1994), RAPD (Random Amplification of Polymorphic DNA) (Haley et al., 1994; Johns et al., 1997), and AFLP (Tohme et al., 1996; Maciel et al., 2003; Šuštar-Vozlič et al., 
2006). Microsatellite markers (or SSRs) have been used in common bean to construct a PCR-based genetic map (Yu et al., 2000; Blair et al., 2003), to evaluate intra-specific diversity within the genus (Gaitan-Solis et al., 2002) and to fingerprint genetic diversity of common beans (Metais et al., 2002). Recently, they were shown useful in distinguishing Andean and Mesoamerican genotypes (Blair et al., 2006; Maras et al., 2006).

The objectives of this work were (1) to evaluate AFLP and SSR marker techniques for their ability to detect genetic diversity within a set of 29 common bean accessions spanning both the Andean and Mesoamerican gene pools and (2) to find out if there is any effect of different marker types on the gene pool classification of common bean accessions.

\section{MATERIAL AND METHODS}

\section{Plant material}

A total of 29 common bean accessions were used in this study (Table 1), including 27 Slovene accessions from the gene bank at the Agricultural Institute of Slovenia and two check accessions ('Michigan Dark Red Kidney' (MDRK) from Andean gene pool and 'Michelite' from Mesoamerican gene pool) from the Institute of Plant Genetics and Crop Plant Research, Gatersleben, Germany. The genetic diversity and the origin of these accessions were assessed in previous study using AFLP (Šuštar-Vozlič et al., 2006) and a part of them (14) was also genotyped in another study using 14 microsatellite markers (Maras et al., 2006). Fifteen accessions were genotyped in addition in this study, using the same microsatellite markers as above.

Table 1: A list of 29 P. vulgaris accessions used in AFLP and SSR analysis.

\begin{tabular}{llll}
\hline Accession & Species name & Accession & Species name \\
\hline PHA7 (5) & P. vulgaris var. vulgaris & PHA418 (3) & P. vulgaris var. nanus \\
PHA11 (3) & P. vulgaris var. vulgaris & PHA423 (3) & P. vulgaris var. nanus \\
PHA15 (5) & P. vulgaris var. vulgaris & PHA438 (5) & P. vulgaris var. nanus \\
PHA29 (5) & P. vulgaris var. vulgaris & PHA452 (3) & P. vulgaris var. nanus \\
PHA59 (3) & P. vulgaris var. vulgaris & PHA498 (3) & P. vulgaris var. nanus \\
PHA153 (5) & P. vulgaris var. vulgaris & PHA639 (3) & P. vulgaris var. vulgaris \\
PHA307 (3) & P. vulgaris var. nanus & PHA642 (1) & P. vulgaris var. vulgaris \\
PHA309 (5) & P. vulgaris var. nanus & PHA717 (3) & P. vulgaris var. vulgaris \\
PHA316 (5) & P. vulgaris var. vulgaris & PHA777 (3) & P. vulgaris var. vulgaris \\
PHA346 (3) & P. vulgaris var. vulgaris & PHA950 (3) & P. vulgaris var. vulgaris \\
PHA358 (5) & P. vulgaris var. nanus & PHA954 (5) & P. vulgaris var. vulgaris \\
PHA363 (5) & P. vulgaris var. nanus & PHA973 (3) & P. vulgaris var. vulgaris \\
PHA374 (1) & P. vulgaris var. vulgaris & Michigan Dark & P. vulgaris var. nanus \\
PHA386 (3) & P. vulgaris var. nanus & Red Kidney (5) & \\
PHA388 (3) & P. vulgaris var. vulgaris & Michelite (5) & P. vulgaris var. vulgaris \\
\hline
\end{tabular}


Accessions, previously analyzed by 14 SSR markers are in normal type, while the fifteen accessions analyzed in addition in this study are in bold type. The numbers in the brackets indicate the number of individual seeds analyzed by microsatellite markers.

\section{DNA extraction}

For the AFLP analysis, fresh leaf samples were taken from 10 field grown plants of each accession, bulked and DNA extracted using a modified CTAB method according to Kump and Javornik (1996). For the SSR analysis, DNA was extracted from single seeds by GenElute Plant Genomic DNA Miniprep Kit (Sigma). The majority of accessions analyzed by SSR markers were represented by three to five individuals (seeds), totaling 107 individuals for all 29 accessions (Table 1).

\section{Molecular analyses}

The AFLP assay was carried out in our previous study (Šuštar-Vozlič et al., 2006). Briefly, $500 \mathrm{ng}$ of DNA was restricted using two restriction enzymes, EcoRI and Msel, and double stranded adaptors ligated to the fragment ends. This was followed by a pre-amplification step using non-selective primers. Selective amplification was performed on the pre-amplified fragment mixture using a total of $10 \mathrm{EcoRI}$ and Msel primer combinations. Amplification products were separated on a $7.5 \%$ polyacrylamide denaturing gel in an automated ALFexpressll sequencer (Amersham Biosciences AB, Uppsala, Sweden).

In addition to 14 accessions previously analyzed by 14 microsatellite markers, 15 new accessions were genotyped following the same procedure as described by Maras et al. (2006). In few words, all forward primers were fluorescently labeled, and the PCR products genotyped on an $\mathrm{ABI}$ Prism 310 Genetic Analyzer (Applied Biosystems). Allele scoring and sizing were performed using GeneScan-350 (Applied Biosystems) internal size standard and GeneScanTM Analysis Software 2.1 (Applied Biosystems).

\section{Band scoring and data analysis}

Profiles for each accession and marker technique (AFLP, SSR) were constructed by scoring 0 and 1 for absence and presence of bands, respectively. In the construction of SSR-based binary matrix, each accession included the number of individuals listed in Table 1. To compare the efficiency of the two marker techniques for diversity assessment in common bean, we estimated the following for each assay unit $(U)$ :

1) Number of polymorphic bands $\left(n_{p}\right)$;

2) Number of monomorphic bands $\left(n_{n p}\right)$;

3) Average number of polymorphic bands per assay unit $\left(n_{p} / U\right)$;

4) Number of loci (L);

5) Number of loci per assay unit: $n_{u}=L / U$;

6) Expected heterozygosity $\left(H_{e}\right)$ of the polymorphic locus for a genetic marker: $H_{e}=1-\Sigma p_{i}^{2}$, where $p_{i}$ is the allele frequency for the $i^{\text {th }}$ allele, and the arithmetic mean of the expected heterozygosity of the polymorphic loci: $\mathrm{H}_{\mathrm{ep}}=\Sigma \mathrm{H}_{\mathrm{e}} / \mathrm{n}_{\mathrm{p}}$;

7) Fraction of polymorphic loci: $\beta=n_{p} / n_{p}+n_{n p}$;

8) Effective multiplex ratio: $E=n_{u} \beta$;

9) Marker index: $\mathrm{MI}=\mathrm{EH}_{\mathrm{ep}}$.

For both matrices, genetic similarity estimates $\left(\mathrm{GS}_{\mathrm{AFLP}}, \mathrm{GS}_{\mathrm{SSR}}\right)$ were calculated using Jaccard's coefficient of similarity (Jaccard, 1908). The accessions were grouped by cluster analysis using the unweighted pair-group method (UPGMA). To determine how accurately the dendrograms represent the estimates of genetic similarity among the genotypes, a cophenetic matrix was generated for each of the dendrograms and compared with the corresponding similarity matrix by the Mantel matrix correspondence test (Mantel, 1967). The same Mantel statistic was used to compare the similarity matrices as well as the dendrograms produced by the AFLP and SSR techniques. All these procedures were performed by appropriate routines in NTSYSpc version 2.0 (Rohlf, 1998). Support for each dendrogram was determined by a bootstrap procedure (100 replications) using the computer package FreeTree (Pavlicek et al., 1999). 


\section{RESULTS}

Both marker techniques were able to uniquely fingerprint each of the 29 bean accessions. The levels of polymorphism detected with each marker technique and the index comparing their informativeness are reported in Table 2. The total number of assays was 10 and 14 primer combinations for AFLP and SSR, respectively. The total number of polymorphic bands ranged from 112 for AFLP to 100 for SSR. An average number of 7.14 polymorphic bands per assay unit was identified for SSR, while for AFLP this number increased to 11.20. Almost twofold higher value of expected heterozygosity was calculated for SSR (0.63) than for AFLP (0.32). The higher marker index value observed for AFLP (3.56) in comparison to SSR (0.63) is the result of a relatively high multiplex ratio component (11.20) of the former.

Table 2: Levels of polymorphism and comparison of the discriminating capacity of AFLP and SSR markers in 29 common bean accessions.

\begin{tabular}{llcc}
\hline Indexes with their abbreviations & & \multicolumn{2}{c}{ Marker system } \\
\cline { 3 - 4 } & & AFLP & SSR \\
\hline Number of assay units & $\mathrm{U}$ & 10 & 14 \\
Number of polymorphic bands & $\mathrm{n}_{\mathrm{p}}$ & 225 & 100 \\
Number of monomorphic bands & $\mathrm{n}_{\mathrm{np}}$ & 11.20 & 0 \\
Average number of polymorphic & $\mathrm{n}_{\mathrm{p}} / \mathrm{U}$ & & 7.14 \\
bands per assay unit & & 337 & 14 \\
Number of loci & $\mathrm{L}$ & 33.70 & 1.00 \\
Number of loci per assay unit & $\mathrm{n}_{\mathrm{u}}$ & 0.32 & 0.63 \\
Expected heterozygosity of the & $\mathrm{H}_{\mathrm{ep}}$ & & \\
polymorphic loci & & 0.33 & 1.00 \\
Fraction of polymorphic loci & $\beta$ & 11.20 & 1.00 \\
Effective multiplex ratio & $\mathrm{E}$ & 3.56 & 0.63 \\
Marker index & $\mathrm{MI}$ & & \\
\hline
\end{tabular}

For all pair-wise comparisons of GS estimates, $\mathrm{GS}_{\mathrm{AFLP}}$ ranged from 0.73 to 0.99 with an average of 0.88 . $\mathrm{GS}_{\mathrm{SSR}}$ ranged from 0 to 0.74 with an average of 0.25 . Accessions PHA346, PHA374, and 'MDRK' shared no SSR allele with accession PHA717. The Mantel test for comparison of the AFLP-based and SSR-based similarity matrices showed moderate but significant correlation $(r=0.69)$.

The dendrograms generated with hierarchical UPGMA cluster analysis of the Jaccard's similarity coefficient matrices revealed two major clusters with $100 \%$ bootstrap values (Figure 1). The cophenetic correlation between the dendrogram and the similarity matrix was moderate for SSR $(\mathrm{r}=0.82)$ and high for AFLP $(\mathrm{r}=$ 0.96). Cluster I contained Andean check accession 'MDRK' and 23 Slovene accessions distributed into two sub-clusters, Sub-cluster I and Sub-cluster II. In addition to Mesoamerican check accession 'Michelite', minor Cluster II contained only four Slovene accessions. Two accessions, PHA438 and PHA346, clustered differently in dendrograms, and these deviations appeared only on the level of the 
sub-clusters. Cophenetic correlation of AFLP-based and SSR-based cophenetic matrices was moderate $(\mathrm{r}=0.78)$ but highly significant.
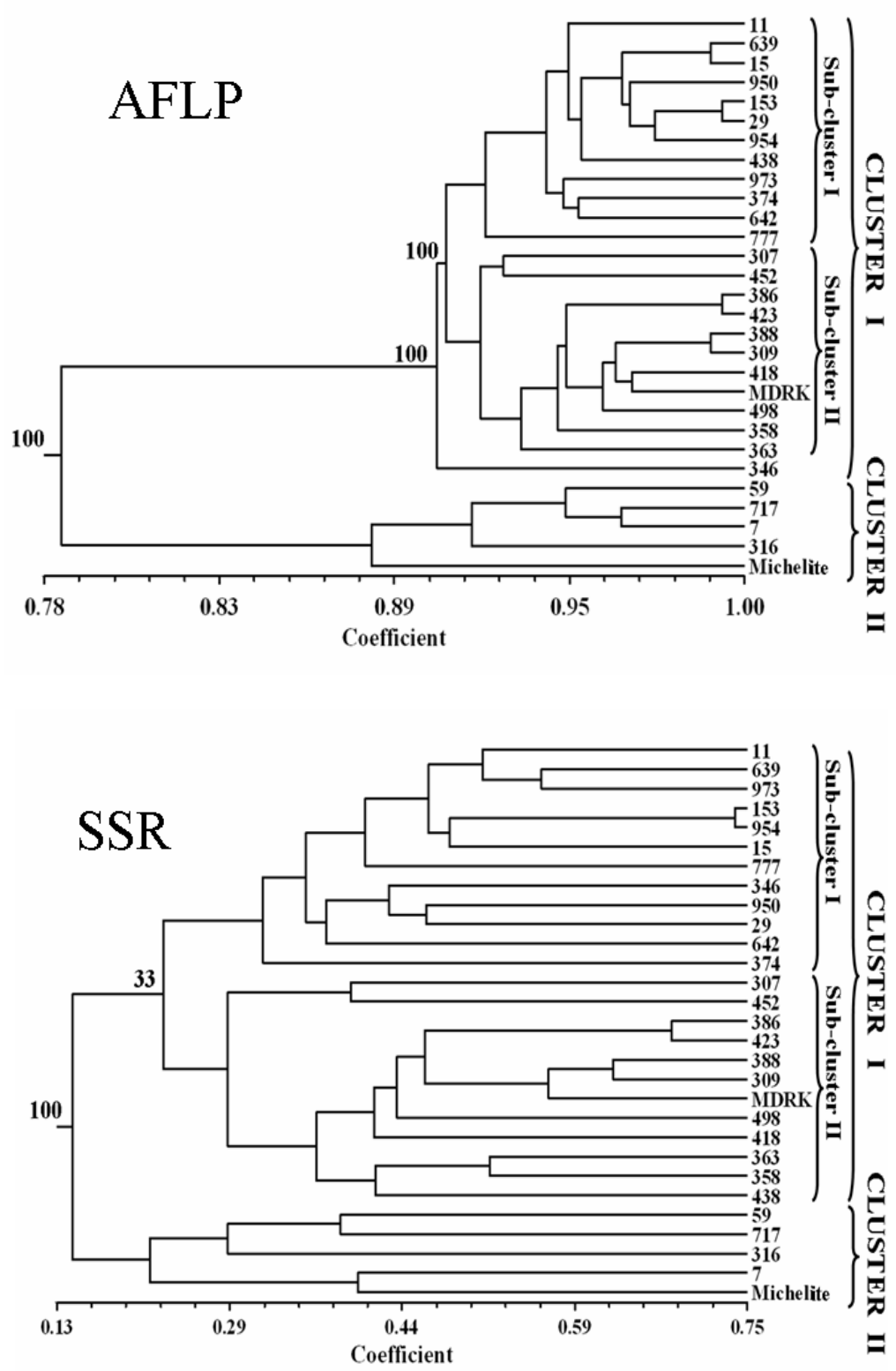

Figure 1: Dendrograms of 29 common bean accessions revealed by cluster analysis of genetic similarity estimates for two different marker sets, AFLP and SSR. 


\section{DISCUSSION}

In this study, we have compared the marker data-sets produced using two different marker systems, AFLP and SSR, to define genetic relationships among 29 common bean accessions, and to investigate which marker system can be more effectively used in the gene pool classification of common bean.

Using AFLP, 10 primer combinations were sufficient to generate 112 polymorphic markers. A total of 100 bands were obtained from the 14 SSR primers amplified and all bands were polymorphic across all the accessions studied. The present study showed that the expected heterozygosity of polymorphic loci for SSR is greater than for AFLP. This relates to the variation of the average number of polymorphic bands per assay unit, which ranged from $33 \%$ for AFLP to a maximum of $100 \%$ for SSR. The higher level of polymorphism detected by SSR markers than with AFLPs highlights the discriminating capacity of the former. The hypervariability observed at SSR loci was expected because of the unique mechanism by which this variation is generated: replication slippage is thought to occur more frequently than single nucleotide mutations and insertion/deletion events, which generate the polymorphisms detectable by AFLP (Powell et al., 1996).

A comparison of the overall efficiency of the two marker systems was provided by the marker index (MI). Almost six-fold higher MI calculated for AFLP in comparison to SSR highlights the distinctive nature of the AFLP assay, which is in concurrence with earlier reports in many plant species (Powell et al., 1996; Belaj et al., 2003; Saini et al., 2004; Medini et al., 2005). The distinctive value of MI for AFLP data is related to the effective multiplex ratio. In other words, it depends more on the high number of polymorphic bands obtained per experiment than on the allelic heterozygosity found among accessions.

The higher level of polymorphism detected by SSR markers has contributed to the lower genetic similarity estimates based on SSR markers (mean 0.25) as compared to AFLP markers (mean 0.88). This is in agreement with other studies comparing the level of polymorphism detected with AFLP and SSR markers in soybean (Powell et al., 1996), maize (Pejic et al., 1998), sorghum (Menz et al., 2003), and triticale (Tams et al., 2005). The moderate and significant correlation here between $\mathrm{GS}_{\mathrm{AFLP}}$ and $\mathrm{GS}_{\mathrm{SSR}}(\mathrm{r}=0.69)$ is comparable with the findings in maize $(\mathrm{r}=0.67)$ (Pejic et al., 1998), and triticale $(r=0.70)$ (Tams et al., 2005). Saini et al. (2004) found even lower correlation between these two marker classes $(0.50)$ in rice and assumed, that this is due to different genomic fractions, involving repeat and/or unique sequences, which may have been differentially evolved or preserved in due course of natural or human selection, that are targeted by these markers.

The cophenetic correlation between the similarity matrix obtained by AFLP analysis and corresponding dendrogram revealed a very high degree of fit $(\mathrm{r}=$ $0.96)$, while moderate cophenetic correlation $(\mathrm{r}=0.82)$ between the similarity matrix obtained by SSR analysis and corresponding dendrogram is probably due to a large number of pair-wise genetic similarity coefficients with intermediate values, which allow a number of similar variants for dendrogram branching (Tams et al., 
2005). This was reflected also in bootstrap analyses, where the node connecting two sub-clusters of major Cluster I appeared in only $33 \%$ bootstrap steps. Nevertheless, both marker techniques revealed a high degree of similarity in dendrogram topologies (Figure 1), because the main clusters in the dendrograms were consistent for both marker systems. All accessions with affiliation to one of the common bean gene pools were assigned to their specific main cluster. Andean Cluster I contained 23 Slovene accessions and check accession 'MDRK'. Only four accessions grouped with 'Michelite', constituting Mesoamerican gene pool. The results suggest that the majority common bean genotypes cultivated in Slovenia are of Andean origin.

In conclusion, we have shown that AFLP and SSR profiling techniques may provide useful information on the level of polymorphism and diversity in common bean, showing their utility in the characterization of germplasm accessions. Both marker systems have comparable accuracy in grouping genotypes of this species according to their gene pool of origin. In respect to germplasm management this is of great significance since genotypes from different gene pools differ in many important agro-ecological traits, including resistance to diseases and pests, growth habit, yield potential, and sensitivity to photoperiod, high temperatures and moisture stress (Singh et al., 1991a).

\section{ACKNOWLEDGEMENTS}

The Institute of Plant Genetics and Crop Plant Research, Gatersleben, Germany, kindly provided the seeds of 'Michelite' and 'Michigan Dark Red Kidney'. The research was supported by grant L4-3284-0401-01 from the Slovenian Ministry of Education, Science and Sport and the Ministry of Agriculture, Forestry and Food.

\section{REFERENCES}

Belaj A., Satovic Z., Cipriani G., Baldoni L, Testolin R, Rallo L, Trujillo I, 2003. Comparative study of the discriminating capacity of RAPD, AFLP and SSR markers and of their effectiveness in establishing genetic relationships in olive. Theoretical and Applied Genetics 107: 736-744.

Blair M.W., Giraldo M.C., Buendía H.F., Tovar E., Duque M.C., Beebe S.E. 2006. Microsatellite marker diversity in common bean (Phaseolus vulgaris L.). Theoretical and Applied Genetics 113: 100-109.

Blair M.W., Pedraza F., Buendia H.F., Gaitan-Solis E., Beebe S.E., Gepts P., Tohme J. 2003. Development of a genome-wide anchored microsatellite map for common bean (Phaseolus vulgaris L.). Theoretical and Applied Genetics 107: 1362-1374.

Debouck D.G., Toro O., Paredes O.M., Johnson W.C., Gepts P. 1993. Genetic diversity and ecological distribution of Phaseolus vulgaris (Fabaceae) in northwestern South America. Economic Botany 47: 408-423.

Gaitan-Solis E., Duque M.C., Edwards K.J., Tohme J. 2002. Microsatellite repeats in common bean (Phaseolus vulgaris): isolation, characterization, and crossspecies amplification in Phaseolus ssp. Crop Science 42: 2128-2136. 
Gepts P., Osborn T.C., Rashka K., Bliss F.A. 1986. Phaseolin-protein variability in wild forms and landraces of the common bean (Phaseolus vulgaris) - evidence for multiple centers of domestication. Economic Botany 40:451-468.

Haley S.D., Miklas P.N., Afanador L., Kelly J.D. 1994. Random amplified polymorphic DNA (RAPD) marker variability between and within gene pools of common bean. Journal of the American Society for Horticultural Science 119:122-125.

Jaccard P. 1908. Nouvelles researches sur la distributiona florale. Bulletin Societe Vaudoise des Sciences Naturelle 44: 223-270.

Johns M.A., Skroch P.W., Nienhuis J., Hinrichsen P., Bascur G., Munoz-Schick C. 1997. Gene pool classification of common bean landraces from Chile based on RAPD and morphological data. Crop Science 37: 605-613.

Kump B., Javornik B. 1996. Evaluation of genetic variability among common buckwheat (Fagopyrum esculentum Moench) populations by RAPD markers. Plant Science 114: $149-158$.

Maciel F.L., Echeverrigaray S., Gerald L.T.S., Grazziotin F.G. 2003. Genetic relationships and diversity among Brazilian cultivars and landraces of common beans (Phaseolus vulgaris L.) revealed by AFLP markers. Genetic Resources and Crop Evolution 50: 887-893.

Mantel N.A. 1967. The detection of disease clustering and a generalized regression approach. Cancer Research 27: 209-220.

Maras M., Sušnik S., Šuštar-Vozlič J., Meglič V. 2006. Temporal changes in genetic diversity of common bean (Phaseolus vulgaris L.) accessions cultivated between 1800 and 2000. Russian Journal of Genetics 42: 775-782.

Medini M., Hamza S., Rebai A., Baum M. 2005. Analysis of genetic diversity in Tunisian durum wheat cultivars and related wild species by SSR and AFLP markers. Genetic Resources and Crop Evolution 52: 21-31.

Menz M.A., Klein R.R., Unruh N.C., Rooney W.L., Klein P.E., Mullet J.E. 2004. Genetic diversity of public inbreds of Sorghum determined by mapped AFLP and SSR markers. Crop Science 44: 1236-1244.

Metais I., Hamon B., Jalouzot R., Peltier D. 2002. Structure and level of genetic diversity in various bean types evidenced with microsatellite markers isolated from a genomic enriched library. Theoretical and Applied Genetics 104: 1346-1352.

Pavlicek A., Hrda S., Flegr J. 1999. FreeTree - Freeware program for construction of phylogenetic trees on the basis of distance data and bootstrap/jackknife analysis of the tree robustness, Application in the RAPD analysis of the genus Frenkelia. Folia Biologica 45: 97-99.

Pejic I., Ajmone-Marsan P., Morgante M., Kozumplick V., Castiglioni P., Taramino G., Motto M. 1998. Comparative analysis of genetic similarity among maize inbred lines detected by RFLPs, RAPDs, SSRs, and AFLPs. Theoretical and Applied Genetics 97: 1248-1255.

Powell W., Morgante M., Andre C., Hanafey M., Vogel J., Tingey S., Rafalski A. 1996. The comparison of RFLP, RAPD, AFLP and SSR (microsatellite) markers for germplasm analysis. Molecular Breeding 2: 225-238.

Rohlf F.J. 1998. NTSYS-pc. Numerical taxonomy and multivariate analysis system, Applied Biostatatistics, New York. 
96 Acta agriculturae Slovenica, 91 - 1, maj 2008

Saini N., Jain N., Jain S., Jain R.K. 2004. Assessment of genetic diversity within and among Basmati and non-Basmati rice varieties using AFLP, ISSR and SSR markers. Euphytica 140: 133-146.

Singh S.P., Gepts P., Debouck D.G. 1991a. Races of common bean (Phaseolus vulgaris, Fabaceae). Economic Botany 45:379-396.

Singh S.P., Nodari R., Gepts P. 1991b. Genetic diversity in cultivated common bean: 1. allozymes. Crop Science 31: 19-23.

Šuštar-Vozlič J., Maras M., Javornik B., Meglič V. 2006. Genetic diversity and origin of Slovene common bean (Phaseolus vulgaris L.) germplasm as revealed by AFLP markers and phaseolin analysis. Journal of the American Society for Horticultural Science 131: 242-249.

Tams S.H., Melchinger A.E., Bauer E. 2005. Genetic similarity among European winter triticale elite germplasms assessed with AFLP and comparisons with SSR and pedigree data. Plant Breeding 124: 154-160.

Tohme J., Gonzalez D.O., Beebe S., Duque M.C. 1996. AFLP analysis of gene pools of a wild bean core collection. Crop Science 36: 1375-1384.

Velasquez V.L.B., Gepts P. 1994. RFLP diversity of common bean (Phaseolus vulgaris) in its centers of origin. Genome 37: 256-263.

Yu K., Park S.J., Poysa V., Gepts P. 2000. Integration of simple sequence repeat (SSR) markers into a molecular linkage map of common bean (Phaseolus vulgaris L.). Journal of Heredity 91: 429-434. 